\title{
Partido e revolução em Lenin, Gramsci e Mariátegui
}

Túlio César Dias Lopes

Resumo: A partir da Revolução Russa, diversos intelectuais se debruçaram na tarefa de formar organizações revolucionárias. O partido político de "novo tipo" na perspectiva leninista superava os limites dos partidos reformistas. $\mathrm{Na}$ concepção gramsciana, o intelectual coletivo ou "moderno príncipe" era necessário ao processo revolucionário. Mariátegui contribuiu com suas experiências e atividades políticas para a construção do partido leninista no Peru. Os três autores convergiram em suas ideias de partido e revolução.

Palavras-chave: Partido. Revolução. Teoria Política. Comunismo.

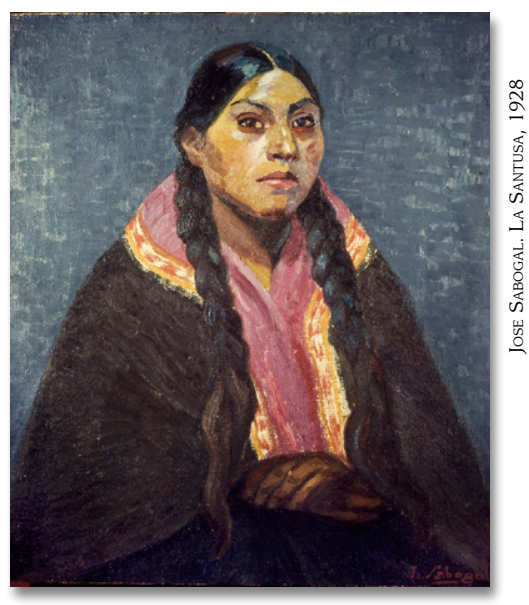

\section{Party and revolution in Lenin, Gramsci and Mariátegui}

\section{Túlio César Dias Lopes}

Historiador pela Universidade Federal de Ouro Preto e Mestre em Educação pela Faculdade de Educação da Universidade Federal de Minas Gerais. Professor substituto na Universidade Federal dos Vales do Jequitinhonha e Mucuri. Membro do Grupo de Estudos e Pesquisa Marx, trabalho e educação.E-mail: tuliodlopes@ yahoo.com.br.
Abstract: With the event of the Russian revolution, several intellectuals focused on the task of forming revolutionary organizations. The role of a "new type" of political party, from a Leninist perspective, surpassed the limits of reformist parties. In the Gramscian conception, the collective intellectual or "modern prince" was necessary for the revolutionary process. Mariátegui contributed his experiences and political activities to build the Leninist Party in Peru. These three authors converged in their ideas of the party and the revolution.

Keywords: Party. Revolution. Political Theory. Communism. 


\section{INTRODUÇÃO}

O debate sobre partido na tradição marxista é bastante polêmico e atual. Vários pensadores (CLAUDÍN, 1986; BOTTOMORE, 1988; HOBSBAWM, 2011) sustentam a tese de que Marx não chegou a elaborar nem a desenvolver uma teoria sistematizada de partido. Todavia, encontramos, em alguns textos marxianos, menções e a defesa dessa nascente forma de organização política da classe trabalhadora.

Na segunda parte do Manifesto do Partido Comunista, Marx e Engels (apud NETTO, 2012) expressam claramente o esboço geral de sua concepção de partido, a partir de uma questão central: a relação entre os proletários e os comunistas.

Qual a relação dos comunistas com os proletários em geral? Os comunistas, em face dos outros partidos operários, não formam um partido à parte. Os comunistas não têm interesses diferentes dos interesses de todo o proletariado. Não estabelecem princípios particulares, com os quais pretendam moldar o movimento operário. Os comunistas se distinguem dos demais partidos proletários apenas porque: 1) nas diferentes lutas nacionais dos proletários acentuam e fazem prevalecer os interesses comuns do proletariado no seu conjunto, independentemente da nacionalidade e 2) nas várias etapas de desenvolvimento por que passa a luta entre o proletariado e a burguesia, representam sempre o interesse do movimento na sua totalidade. Os comunistas são, pois, na prática, a fração mais decidida, aquela que impulsiona todas as outras, dos partidos operários de todos os países; teoricamente, excedem a massa restante do proletariado pela compreensão das condições, do curso e dos objetivos gerais do movimento proletário. O Objetivo imediato dos comunistas é o mesmo de todos os demais partidos proletários: constituição do proletariado em classe, derrubada do domínio da burguesia, conquista do poder político pelo proletariado (MARX; ENGELS apud NETTO, 2012, p.197).

Ainda no Manifesto do Partido Comunista, Marx e Engels destacam a luta dos comunistas nos partidos comunistas, socialistas e 
operários da época, ressaltando que "os comunistas lutam para realizar os fins e interesses imediatos da classe operária, mas representam, no movimento presente, o futuro do movimento" (MARX; ENGELS apud NETTO, 2012, p. 215 - 216). Eles reforçam que "em toda a parte os comunistas apoiam todos os movimentos revolucionários contra as condições sociais e políticas existentes" (MARX; ENGELS apud NETTO, 2012, p. 216) e sublinham que a superação da questão da propriedade privada é o objetivo principal dos comunistas. A defesa da unidade política é expressa na parte final do manifesto: "os comunistas trabalham pela união e pelo entendimento dos partidários democráticos de todos os países" (MARX; ENGELS apud NETTO, 2012, p. 216).

Como o texto deixa claro, o partido comunista de Marx e Engels, nessa fase, não era e nem tentava criar uma organização, muito menos uma organização com um programa específico diferente de outras organizações. Diga-se de passagem, a entidade em cujo nome o Manifesto foi escrito, a Liga Comunista, em nenhum momento é mencionada no documento.

As discussões sobre como promover a luta pela superação da sociedade de classes baseada na propriedade privada esbarram na problemática da organização (partido) e na relação entre o partido e os sindicatos, movimentos, entidades e, principalmente, a classe que pretende representar. Na tradição revolucionária da cultura política socialista e comunista, a questão do partido é trivial.

O operador político (partido), além de organizar os trabalhadores para o enfrentamento contra o capital, busca desenvolver a consciência socialista. Em outras palavras, cabe ao partido organizar, através das mediações necessárias, o proletariado e desenvolver a consciência de classe indispensável para o avanço dos trabalhadores, na luta pelo socialismo na perspectiva do comunismo.

Apresentando uma abordagem histórica sobre a noção de partido político presente na obra marxiana, o historiador Eric Hobsbawm (2011) destaca que:

A palavra "partido" não tem aqui as acepções que adquiriu mais tarde, e não há nos textos de Marx e Engels referência alguma a tais acepções. Em meados do século XIX, a palavra indicava tanto os adeptos de um ideário 
ou causa política quanto os membros de um grupo formal organizado. Na década de 1850, Marx e Engels usavam a palavra com frequência para se referir à Liga Comunista (...).É evidente que, a partir da década de 1870, Marx e Engels apoiaram, onde possível, a formação de um partido político organizado, desde que não fosse uma seita; e era natural que, nos partidos formados por seus seguidores ou sob a influência deles, problemas de organização interna, estrutura, disciplina etc. requeressem opiniões emanadas de Londres. Os que melhor compreendem o sentido oculto da luta de classes, que acontece diante de nossos olhos - os comunistas - devem ser os últimos a cometer o erro de aprovar ou promover o sectarismo. O partido deveria pretender ser a classe organizada, e Marx e Engels nunca se desviaram do que haviam declarado no Manifesto: que os comunistas não constituíam um partido separado, oposto a outros partidos da classe operária, nem criavam princípios sectários próprios com os quais moldar o movimento proletário. (HOBSBAWM, 2011, p. 63).

Na perspectiva de Hobsbawm (2011), o partido comunista que aparece no Manifesto não tem nada a ver com os partidos da política democrática moderna ou com os partidos de vanguarda do comunismo leninista, muito menos com os partidos estatais de tipo soviético ou chinês. Nada disso existia. Partido ainda significava, em essência, uma tendência, uma corrente de opinião ou uma política. Ainda que Marx e Engels reconhecessem que nem bem essas tendências, correntes de opinião ou políticas encontravam expressões em movimentos de classe, eles adquiriam algum tipo de organização (HOBSBAWM, 2011).

Mészáros (2015), mesmo não fazendo nenhuma alusão explícita a partidos e organizações políticas, destaca a ênfase dada por Marx ao fato de que é inconcebível uma transformação histórica "sem o permanente trabalho revolucionário do que ele chamou de 'organismo de crítica prática', ou seja, a classe trabalhadora internacional organizada” (MÉSZÁROS, 2015, p. 40).

As experiências históricas desenvolvidas pelas organizações políticas ligadas à classe trabalhadora tiveram como síntese a 
constituição de partidos políticos. Os partidos operários europeus tiveram na II Internacional seu espaço de articulação internacional e unidade política. Com o desencadeamento da Primeira Guerra Mundial (1914 - 1918), ocorreu uma fissura na I Internacional que ocasionou uma série de cisões e rupturas.

\section{LÊNIN E O PARTIDO DE NOVO TIPO}

Lênin' foi o principal dirigente do "Partido Bolchevique na Revolução de outubro de 1917, que levou ao poder na Rússia o primeiro Estado Socialista do mundo" (BOTTOMORE, 1988, p. 211). Através da Internacional Comunista (1919 - 1943), "suas concepções se espalharam por todo o mundo, definindo o Comunismo moderno, em oposição à socialdemocracia" (BOTTOMORE, 1988, p. 211).

Lênin, em seu prefácio à primeira edição de Estado e Revolução de 1917, afirmou que a questão do Estado está na ordem do dia da Revolução Russa, em particular, e de todas as revoluções, de uma maneira geral, devido ao fato de que "a guerra imperialista acelerou e avivou ao mais alto grau o processo de transformação do capitalismo monopolizador em capitalismo monopolizador de Estado" (LÊNIN, 2011, p. 31).

Ao afirmar a importância da questão do Estado, Lênin (2011) destacava que "a revolução proletária universal está em maturação e a questão das suas relações com o Estado adquire, praticamente, um caráter de atualidade" (LÊNIN, 2011, p. 31). E, permanece atual, pois é o "divisor de águas" principal entre a esquerda revolucionária e os reformistas.

De acordo com Lênin (2011), a luta da classe trabalhadora para se libertar da influência burguesa (e da burguesia imperialista) não deve se desassociar da luta contra "os preconceitos oportunistas

\footnotetext{
1 Vladimir Ilitch Ulianov, Lênin nasceu na Rússia em 22 de abril de 1870. É considerado o "mais influente líder e teórico político do marxismo no século XX". É atribuída a Lênin a revitalização da "teoria da revolução do marxismo, ao acentuar a importância da luta de classes ser dirigida por um partido coesamente organizado". No campo do marxismo seu estudo sobre "Imperialismo, como estágio final do capitalismo" em que "estariam dadas as condições para uma revolução proletária internacional, que se estabeleceria e se manteria pela força, numa ditadura do proletariado transitória" (BOTTOMORE, 1988, p. 211).
} 
em relação ao Estado". Ao abordar a relação entre as classes sociais e o Estado, ele afirma que "o Estado é um produto e a manifestação do antagonismo inconciliável das classes" (LÊNIN, 2011, p. 37), resumindo a questão do Estado para o marxismo da seguinte forma: "O Estado aparece onde e na medida em que os antagonismos de classes não podem objetivamente ser conciliados. E, reciprocamente, a existência do Estado prova que as contradições de classes são inconciliáveis" (LÊNIN, 2011, p. 37).

Em polêmica oposição às tendências tidas por Lênin (2011) como oportunistas, o revolucionário russo afirma que "Para Marx, o Estado é um órgão de dominação de classe, um órgão de submissão de uma classe por outra; é a criação de uma 'ordem' que legalize e consolide essa submissão, amortecendo a colisão das classes" (LÊNIN, 2011, p. 38).

Implacável na crítica aos seus adversários, Lênin (2011) distingue as posições dos marxistas revolucionários (bolcheviques) das posições dos mencheviques e dos socialistas revolucionários, defensores da democracia pequeno-burguesa através da fraseologia socialista. Na perspectiva elucidada por Lênin (2011), a existência do Estado e seu caráter opressor geram, consequentemente, uma dominação de uma classe sobre a outra, o que torna impossível a conciliação de classes no interior deste Estado. Outra diferença marcante entre os marxistas revolucionários e as demais correntes políticas do movimento operário é a concepção de partido político.

Fernando Claudín (1986) destaca que, através da obra O que fazer?, "Lênin inaugura, na história do marxismo, o culto do partido; do partido depositário da ortodoxia marxista, portador da consciência socialista, organizador e dirigente da classe operária, instrumento decisivo da revolução" (CLAUDíN, 1986, p.67). No decorrer dos séculos XX e XXI, diversos partidos e organizações políticas têm essa obra como referência de organização para o trabalho político. 
Lênin ${ }^{2}$ (2011) sublinha a necessidade histórica do partido vinculado às lutas da classe trabalhadora. Esse partido deveria ser formado por militantes profissionais dedicados e disciplinados:

Educando o partido operário, o marxismo forma a vanguarda do proletariado, capaz de tomar o poder e de conduzir todo o povo ao socialismo, capaz de dirigir e de organizar um novo regime, de ser o instrutor, o chefe e o guia de todos os trabalhadores, de todos os exploradores, para a criação de uma sociedade sem burguesia, e isto contra a burguesia. (LÊNIN, 2011, p. 60).

O partido político de novo tipo, na perspectiva leninista, exerce potencialmente o papel central de educação política dos quadros e dos militantes, a partir do referencial teórico do marxismo, para garantir a direção consciente do movimento espontâneo da classe trabalhadora. É necessário destacar o papel do princípio político organizativo do partido revolucionário concebido por Lênin: o centralismo democrático. Lênin (2011) reforça a necessidade da ação política centralizada e organizada do partido revolucionário como condição indispensável para a luta revolucionária. A liberdade de discussão crítica e autocrítica, dentro das instâncias partidárias, corresponde à democracia. A ação unitária, planejada, hierarquizada e disciplinada corresponde ao elemento do centralismo.

Em relação à atividade partidária, Lênin (2009) destaca que, no tocante à direção ideológica e prática do movimento e da luta revolucionária do proletariado, é necessária a maior centralização possível com relação à informação do centro do partido (e, consequentemente, de todo o partido em geral). Assim, no que diz respeito ao movimento e à responsabilidade ante ao partido, se impõe a maior descentralização possível. Todavia, esse princípio organizativo fora desrespeitado em diversos cenários, dando

\footnotetext{
2 Motta (2014) afirma que "a grande contribuição teórico-política de Lênin (para além da questão do imperialismo) é a questão da organização política revolucionária para a derrubada do Estado capitalista", pois "Lênin dá um novo sentido ao partido político da classe trabalhadora ao demarcar uma distinção com o modelo dos partidos de massa, definindo o papel de vanguarda aos militantes revolucionários, e a consciência externa à classe proletária, em oposição ao espontaneísmo." (MOTTA, 2014, p.119).
} 
origem ao centralismo-burocrático, ao centralismo ou ao democratismo nas fileiras partidárias.

Uma questão fundamental atribuída ao pensamento de Lênin e presente na obra fundadora de sua concepção de partido é a defesa da seguinte perspectiva revolucionária: a consciência política de classe não pode ser levada ao operário senão do exterior, isto é, de fora da luta econômica, de fora da esfera das relações entre operários e patrões (LÊNIN, 2009). Caberia ao partido, o combate ao espontaneísmo e principalmente a luta ideológica contra a influência do pensamento burguês na classe trabalhadora. Nesse sentido, o partido revolucionário seria criado e guiado por uma teoria revolucionária (marxismo), "segundo princípios, uma política, um plano e formas organizacionais previamente elaborados pelos intelectuais marxistas, depositários do 'socialismo científico'." (CLAUDíN, 1986, p. 673).

Outra questão que se relaciona diretamente à educação das "massas" é a agitação e propaganda. Cabe aos instrumentos de organização, agitação e propaganda do partido revolucionário panfletos, jornais, revistas, livros - estabelecer a conexão política com a classe trabalhadora. Através da práxis revolucionária de seus quadros e seus militantes, nos movimentos sociais, estudantis, sindicais e populares, o partido busca exercer a hegemonia e influenciar a política e os rumos do movimento. Lênin (2009) atribui um papel decisivo ao jornal do partido revolucionário e alerta para sua fundamental importância:

Um jornal, todavia, não tem somente a função de difundir ideias, de educar politicamente e de conquistar aliados políticos. O jornal não é apenas um propagandista e agitador coletivo, mas também um organizador coletivo. A esse respeito, se pode compará-lo aos andaimes que se levantam ao redor de um edifício em construção; constitui o esboço dos contornos do edifício, facilita as comunicações entre os diferentes construtores, permitindo-lhes que repartam a tarefa e atinjam o conjunto dos resultados obtidos pelo trabalho organizado. Através do jornal e com o jornal se formará uma organização permanente, que se ocupará não somente do trabalho local, mas também do trabalho geral sistemático, que 
ensinará a seus membros a acompanharem atentamente os acontecimentos políticos, a avaliar a importância e a influência de diversos estratos da população, a elaborar quais métodos permitem ao partido revolucionário exercitar sua influência sobre os mesmos. (LÊNIN, 2009, p. 70).

A relação entre os estudantes e o movimento operário e campesino é explícita na abordagem leninista. Aos estudantes, cabe a tarefa de apoiar as agitações operárias e os levantamentos campesinos. Ao partido e aos operários e campesinos, o apoio e a solidariedade aos estudantes são triviais e as ações do movimento operário contribuem diretamente para emular o "espírito revolucionário" e promover a luta das outras camadas sociais.

Em um texto publicado na revista Zaria, em 1901, Lênin (1977) destaca uma lição a aprender:

Devemos extrair dela (a lição da ação dos socialdemocratas) uma lição renovada da omnipotência do movimento operário que dirigimos, observando como a agitação existente na classe revolucionária de vanguarda se transmite a outras classes e camadas da sociedade, que essa agitação conduziu não só a um auge jamais visto do espírito revolucionário no seio da estudantada, mas também ao início do despertar da aldeia e robustecimento da confiança em si próprios e disposição para a luta em grupos sociais que (como grupos) se mantinham até agora pouco sensíveis. (LÊNIN, 1977, p. 79).

Em nota, no mesmo texto, Lênin (1977) conclui sublinhando que:

[...] talvez a história também queira atribuir ao estudantado o papel de promotor no choque decisivo. De qualquer modo, para vencer esse choque, torna-se imprescindível o auge das massas do proletariado, e é nosso dever ocupar-nos quanto antes da elevação do grau da sua consciência, espírito de luta e organização. (LÊNIN, 1977, p. 79).

Lênin (1977) se refere à crescente agitação nos meios estudantis em Kiev, Petersburgo e outras cidades, além da formação de grupos estudantis revolucionários em Odessa. 
Ao tratar do recrutamento militar forçado de 183 estudantes nas fileiras do exército, acusados de agitação nas universidades, Lênin (1977) destaca, em sua monumental obra Que Fazer?, que o jornal ISKRA havia publicado um artigo sobre o fato "e antes que qualquer manifestação principiasse, exortou diretamente 'o operário a acudir em auxílio do estudante', exortou o 'povo' a contestar abertamente o insolente desafio do governo [...]". (LÊNIN, 1977, p. 80).

A influência liberal entre os estudantes também é identificada, analisada e repelida. Ao destacar o papel do comitê executivo dos estudantes de Moscou, Lênin (1977) diz que:

os estudantes que, começando a compreender a necessidade da luta política, a empreenderam e, ao mesmo tempo, fustigamos 'a bárbara incompreensão 'dos partidários do movimento 'puramente universitário' que incitam os estudantes a não participar nas manifestações de rua... quem vir em semelhante tática um obscurecimento da consciência de classe do proletariado e um compromisso com o liberalismo revela que não compreende de modo algum o verdadeiro sentido do programa do 'Credo' e, na realidade, aplica precisamente esse programa, por muito que o repudie! Porque, por isso mesmo, arrasta a socialdemocracia para 'a luta econômica contra os patronos do governo' e retrocede perante o liberalismo, renunciando à tarefa de intervir ativamente em cada problema de natureza 'liberal' e determinar, em face de cada um desses problemas, a sua própria atitude, a sua atitude socialdemocrata. (LÊNIN, 1977 , p. $80-81$ ).

Sobre a organização dos estudantes no partido, Lênin (1977) destaca a necessidade da formação de um comitê de revolucionários profissionais. Na perspectiva que o líder revolucionário russo elucida:

[...] um comitê formado por estudantes não nos convém, porque é instável. Absolutamente justo! Mas a conclusão a extrair daí consiste em que faz falta um comitê de revolucionários profissionais, sem que interesse se são estudantes ou operários que se mostram capazes de se forjar como revolucionários profissionais [...]. Permiti-me uma pergunta: de que modo "estimularam" os 
nossos estudantes, até agora, os nossos operários? Unicamente proporcionando-lhes os fragmentos de conhecimentos políticos que possuíam, os fragmentos de ideias socialistas que tinham podido adquirir (pois o principal alimento espiritual do estudante dos nossos dias, o marxismo legal, "só lhe pode fornecer o abecedário, só lhe pode fornecer fragmentos") [...]. (LÊNIN, 1977, p. 81).

Além da propagação das ideias revolucionárias, seria necessário substituir os métodos primitivos de organização por uma organização forte e sólida, formada por estudantes, intelectuais, campesinos e operários. Ao abordar a questão das agitações estudantis a favor de questões acadêmicas, ao invés de repudiar aprioristicamente tais ações, Lênin (1977) destaca a necessidade de impulsionar o movimento associando à luta acadêmica as lutas políticas. Os estudantes sociais-democratas têm uma tarefa objetiva nas instituições acadêmicas:

A nossa tarefa reside em explicar à massa de protestantes "acadêmicos" a significação objetiva do conflito, em procurar convertê-lo num movimento político consciente, em duplicar a ação de agitação dos grupos sociaisdemocratas de estudantes e orientar toda essa atividade para que sejam assimiladas as conclusões revolucionárias da história de três anos, para que se compreenda a inevitabilidade de uma nova luta revolucionária, para que as nossas velhas aspirações - que continuam sendo plenamente atuais - de derrube da autocracia e de convocatória da Assembléia Constituinte tornem a ser objeto de discussão e pedra-de-toque da concentração política das gerações viçosas da democracia. (LÊNIN, 1977, p.38).

A renúncia à luta nas instituições acadêmicas é tida como um traço liberal a ser combatido. A tarefa dos estudantes sociais-democratas é organizar e impulsionar a luta dentro das instituições acadêmicas, associando-a às lutas políticas gerais, encabeçadas pelo partido e protagonizadas pelos movimentos operários e campesinos.

Os estudantes sociais-democratas não tem o direito de renunciar a semelhante atividade, quaisquer que sejam as circunstâncias, 
qualquer que seja essa atividade no momento presente; por muitos que sejam os insucessos sofridos por uns ou outros agitadores numa ou outra universidade, associação de estudantes, assembleia, etc, dir-lhe-emos: "Batei e abrir-vos-ão a porta" O seu êxito não se mede apenas pelo fato de termos conseguido, agora e aqui, a maioria ou acordo para a ação política coordenada. É possível que não o consigamos no momento: precisamente por sermos um partido proletário organizado, não nos devemos perturbar com os reveses transitórios, mas realizar a nossa ação com tenacidade, de forma imutável, com firmeza e mesmo nas condições mais difíceis. (LÊNIN, 1977, p.38 - 39).

Esse modelo leninista de organização política partidária deu origem a diversos partidos comunistas e operários, tendo como fator propulsor o êxito bolchevique na Revolução Russa de 1917. O surgimento da III Internacional, a Internacional Comunista (1919 - 1943), agregando diversos partidos comunistas e operários, contribuiu significativamente para a constituição e o crescimento quantitativo e qualitativo dessas organizações.

Após apresentarmos a concepção de partido revolucionário desenvolvida por Lênin, cabe destacarmos as contribuições de Gramsci. Segundo Hobsbawm (2011): "Gramsci é profundamente leninista em sua visão geral do papel do partido", discordando de aspectos organizativos e "em relação à natureza da vida do partido" (HOBSBAWM, 2011, p. 294). Verificamos, nesta perspectiva, "que suas ideias sobre a natureza e as funções dos partidos, vão além das de Lênin" (HOBSBAWM, 2011, p. 294). Portanto, embora Gramsci tivesse como referência política organizativa as ideias e concepções leninistas de partido, ele procurou adaptá-las ao contexto histórico italiano.

\section{GRAMSCI, O PARTIDO LENINISTA E O PRÍNCIPE MODERNO}

Antônio Gramsci nasceu em 22 de janeiro de 1891, em Ales (Sardenha). Ingressou no ensino médio em Cagliari e participou ativamente dos grupos juvenis que discutem os problemas 
econômicos e sociais da Sardenha. Em 1912, concluiu o ensino médio e obteve uma bolsa de estudos, que lhe permitiu matricular-se na Faculdade de Letras da Universidade de Turim. Em 1913, ingressou na seção de Turim do Partido Socialista Italiano (PSI). Em 1915, abandonou a universidade para se dedicar integralmente ao jornalismo e à política. Participou, em setembro de 1920, do movimento de ocupação das fábricas, que culminou em derrota. Em 21 de janeiro de 1921, participou da fundação do Partido Comunista da Itália - Seção Italiana da Internacional Comunista. Em abril de 1924, foi eleito deputado. Em novembro de 1926, foi preso junto a outros deputados comunistas. Em outubro de 1934, lhe foi concedida a liberdade condicional. Em abril de 1937, readquiriu liberdade plena, mas morreu no dia 27 de abril de 1937 (COUTINHO, 2011).

Gramsci (1966), ao apresentar sua concepção de partido, retoma as discussões promovidas por Lênin acerca da consciência revolucionária dos militantes comunistas. Segundo o autor italiano:

De certo, não se pode exigir que cada operário tenha uma completa consciência de toda a complexa função que sua classe está destinada a desempenhar no processo de desenvolvimento da humanidade, mas isso deve ser exigido dos membros do Partido. (...) Mas o Partido pode e deve, em seu conjunto, representar esta consciência superior; de resto, se não fizer isso, não estará à frente das massas, mas em sua retaguarda; não as dirigirá, mas será arrastado por elas. Por isso, o Partido deve assimilar o marxismo - e deve assimilá -lo em sua forma atual, ou seja, o leninismo. (GRAMSCI, 1966, p. 100).

A assimilação teórica do marxismo e a compreensão prática do leninismo é uma exigência constante e regular para a formação dos quadros e dos militantes do partido revolucionário. O ingresso no partido revolucionário teria critérios, tais como se submeter à disciplina partidária e à linha política das organizações.

Abordando elementos relacionados ao debate sobre a relação entre partido e Estado, Gramsci (1966) nos apresenta uma importante contribuição: 
A função hegemônica ou de direção política dos partidos pode ser avaliada pelo desenvolvimento da vida interna dos próprios partidos. Se o Estado representa a força coercitiva e punitiva de regulamentação jurídica de um país, os partidos, representando a adesão espontânea de uma elite a tal regulamentação, considerada como tipo de convivência coletiva para a qual toda a massa deve ser educada, devem mostrar em sua vida particular e interna terem assimilado, como princípios de conduta moral, aquelas regras que no Estado são obrigações legais. Nos partidos, a necessidade já se tornou liberdade, e daí nasce o enorme valor político (isto é, de direção política) da disciplina interna de um partido e, portanto, o valor do critério que tem tal disciplina para avaliar a força de expansão dos diversos partidos. Deste ponto de vista, os partidos podem ser considerados como escolas da vida estatal. (GRAMSCI, 1966, p.307 - 308).

Essa passagem ilustra a importância atribuída aos partidos políticos no campo da educação política e, principalmente, "como escolas da vida estatal" capazes de aglutinar pessoas e empreender ações políticas em diversos setores da sociedade, conduzindo e transformando conscientemente as ações espontâneas das massas trabalhadoras, preparando-as para o exercício do poder popular.

Gramsci (1966), ao se referir ao partido político como o moderno príncipe, destaca o papel coletivo desempenhado por essa organização de novo tipo, afirmando que:

O moderno príncipe, o mito-príncipe não pode ser uma pessoa real, um indivíduo concreto, só pode ser um organismo; um elemento complexo de sociedade no qual já tenha tido início a concretização de uma vontade coletiva reconhecida e afirmada parcialmente na ação. Este organismo já está dado pelo desenvolvimento histórico e é o partido político, a primeira célula na qual se sintetizam germes de vontade coletiva que tendem a se tornar universais e totais. (GRAMSCI, 1966, p. 238).

Esse líder comunista italiano também apresenta alguns elementos centrais na vida dos partidos relacionados ao "caráter (resistência aos impulsos das culturas ultrapassadas), honra (vontade intrépida 
ao sustentar o novo tipo de cultura e de vida), dignidade (consciência de operar por um fim superior)" (GRAMSCI, 1966, p. 308).

Para Gramsci (1966), a vinculação teórica do partido com a teoria socialista é fundamental.

Para o Partido da classe operária, que é tal precisamente porque resume e representa todas as exigências da luta geral, as três frentes da luta proletária (se reduzem a uma só. Decerto, não se pode exigir que cada operário tenha uma completa consciência de toda a complexa função que sua classe está destinada a desempenhar no processo de desenvolvimento da humanidade, mas isso deve ser exigido aos membros do Partido. Não é possível propor, antes da conquista do Estado, a modificação completa da consciência de toda a classe operária; isso seria utópico, já que a consciência de classe também se modificar, ou seja, quando o proletariado se transformar em classe dominante, quando tiver à sua disposição o aparelho de produção e de troca e o poder estatal. Mas o partido pode e deve, em seu conjunto, representar esta consciência superior; de resto, se não fizer isso, não estará à frente das massas, mas em sua retaguarda; não as dirigirá, mas será arrastado por elas. Por isso, o Partido deve assimilar o marxismo - e deve assimilá-lo em sua forma atual, ou seja, como leninismo. (GRAMSCI, 1966, p. 99 - 100).

Na referência sobre a escrita histórica da trajetória dos partidos políticos, ele apresenta a seguinte recomendação: "Quando se quer escrever a história de um partido político, deve-se enfrentar a realidade toda uma série de problemas muito menos simples do que aqueles imaginados" (GRAMSCI, 1966, p. 300).

Em seus escritos pré-carcerários (1916 - 1919), Gramsci apresenta uma rica contribuição acerca das atribuições de um partido político, um partido comunista, inserido na "luta do proletariado contra o capitalismo", que deve atuar "em três frentes: a econômica, a política e a ideológica" (GRAMSCI, 1966, p. 98). Em relação à luta econômica, essa se apresenta em "três fases: de resistência contra o capitalismo, ou seja, a fase sindical elementar; de ofensiva contra o capitalismo pelo controle operário da produção; 
de luta pela eliminação do capitalismo através da socialização" (GRAMSCI, 1966, p. 98).

Gramsci (1966) atribui um papel central à luta política que se manifesta em três fases principais:

[...] luta para limitar o poder da burguesia no Estado parlamentar, ou seja, para manter ou criar uma situação democrática de equilíbrio entre as classes, que permita ao proletariado organizar-se e desenvolver-se; luta pela conquista do poder e pela criação do Estado operário,, ou seja, uma ação política complexa através do qual o proletariado mobiliza em torno de si todas as forças sociais anticapitalistas (em primeiro lugar, a classe camponesa) e as conduz à vitória; a fase da ditadura do proletariado, organizado em classe dominante a fim de eliminar todos os obstáculos técnicos e sociais que se opõem à realização do comunismo. A luta econômica não pode ser desligada da luta política e nenhuma das duas pode ser desligada da luta ideológica. (GRAMSCI, 1966, p. 99).

Daí o papel de destaque atribuído por Gramsci (1966) ao "partido da classe operária, que é tal precisamente porque resume e representa todas as exigências da luta geral, as três frentes da luta proletária se reduzem a uma só" (GRAMSCI, 1966, p. 100). Ele ainda sustenta que a atividade teórica é a luta na frente ideológica e, "para lutar contra a ideologia burguesa, ou seja, para libertar as massas da influência do capitalismo, fosse necessário, antes de mais nada, difundir no próprio partido a doutrina marxista e defendê-la contra todas as deformações" (GRAMSCI, 1966, p. 100). Neste sentido, "é necessário que o partido intensifique e torne sistemática sua atividade no campo ideológico, que ele ponha como dever do militante o conhecimento das doutrinas do marxismo-leninismo, pelo menos em seus aspectos mais gerais" (GRAMSCI, 1966, p. 100).

Gramsci (1966) reforça a necessidade de um permanente contato com as massas, através do trabalho intenso de cada membro do partido enquanto um "elemento político ativo, um dirigente" (GRAMSCI, 1966, p. 101). Ele ressalta que, precisamente porque o partido é fortemente centralizado, deve haver uma ampla obra de propaganda e de agitação em suas fileiras; é preciso que o partido, 
de modo organizado, eduque seus membros e eleve seu nível ideológico.

As contribuições teóricas e políticas de Antônio Gramsci influenciaram sobremaneira a construção do Partido Comunista Italiano e posteriormente a formação de uma corrente ideológica no seio do movimento comunista internacional, o eurocomunismo. Cabe destacarmos a diversidade e pluralidade de análises provenientes dos estudos da vida e da obra deste pensador italiano. Neste artigo, procuramos enfocar suas contribuições acerca do partido político. Na Itália, existem atualmente duas organizações comunistas, a Refundação Comunista (RC) e o Partido dos Comunistas Italianos. Ambas buscam reconstruir o Partido Comunista Italiano (PCI), fundado por Antônio Gramsci e dissolvido em 1991, no auge da crise do Movimento Comunista Internacional.

\section{MARIÁTEGUI: A CONSTRUÇÃO DO PARTIDO REVOLUCIONÁRIO}

José Carlos Mariátegui nasceu em Moquega, sul do Peru, em 14 de junho de 1894. Em 1909, deslocou-se com sua família para Lima, começou a desempenhar suas atividades profissionais como auxiliar de tipografia no jornal La Prensa, um diário liberal-conservador. No jornal La Prensa, das oficinas passou à redação e, a partir de 1914, começou a desenvolver sua atividade jornalística e literária. Ainda em 1916, Mariátegui integrou a redação do diário El Tiempo. Em 1918, criou com César Falcón e Félix del Valle a revista Nuestra Época. Mariátegui criou um novo diário em 1919, intitulado La Razón. Ainda em 1919, o jornal La Razón deixou de circular, tendo sido fechado pelo governo que percebia também a necessidade de afastar Mariátegui da cena política a qual estava ligado mediante suas publicações. No final de 1919, Mariátegui embarcou para a Itália, a "convite" do governo peruano.

Em 1921, Mariátegui assistiu ao Congresso de Livorno, que marcou a fundação do Partido Comunista Italiano. Em sua estadia na Itália, Mariátegui não só estudou autores que começavam a encontrar ressonância (como Freud, por exemplo), como também se voltou para a literatura socialista e comunista. Da Europa, 
retornou para o Peru com forte influência marxista, levando planos e projetos. Entre 1924 e 1926, dedicou-se ao trabalho político-jornalístico, assumiu a direção da revista Claridad (órgão de imprensa da Universidade Popular Gonzáles Prada) e para o jornal El Obrero Textil. Ainda em 1925, organizou a Editorial LibreríaImprensa Minerva e, no ano seguinte, consolidou seu projeto com a publicação de seu primeiro livro, chamado La escena contemporânea, e o começo da circulação da revista Amauta. Em meio a proibições e prisões de seus membros, a revista Amauta ganhou prestígio internacional. Paralelamente à Amauta, Mariátegui dedicou-se a um periódico que criara no mesmo ano, voltado para a organização política do proletariado, Labor, que circulará entre 1928 e 1929. Ainda em 1928, Mariátegui publicou seu segundo livro, os Siete ensayos de interpretación de la realidade peruana. Além da atividade política-jornalistica, José Carlos Mariátegui inclinou-se para a participação direta na vida política peruana.

Mariátegui criou, em 1928, o Partido Socialista do Peru (PSP), transformado depois em Partido Comunista Peruano (PCP), sendolhe atribuída a Secretária Geral (presidência) desse novo partido. Em 1929, criou a Confederação Geral dos Trabalhadores do Peru (CGTP). No auge de suas atividades, temendo represálias, transferiu-se para Buenos Aires com sua família. José Carlos Mariátegui morreu em abril de 1930, sendo homenageado no Peru e em círculos socialistas e comunistas de outros países (ESCORSIM, 2006).

No início do século XX, as ideias marxistas começaram a circular com maior fluidez na América Latina. Vários intelectuais, líderes operários, camponeses e estudantes começaram a ter acesso à literatura marxista, antes restrita à Europa e aos Estados Unidos da América. O movimento socialista internacional ganhava fôlego com a Revolução Socialista Soviética na Rússia, em 1917, e a organização da Internacional Comunista (KOMINTERN), em 1919.

Sob a influência da Revolução Russa, foram formados os primeiros partidos comunistas latino-americanos. José Carlos Mariátegui, no Peru, foi um dos principais precursores do marxismo na América Latina. Suas contribuições teóricas e sua atuação política foram decisivas para a construção do PSP, futuramente PCP. Cabe destacarmos o papel desempenhado por esse intelectual 
revolucionário na difusão das ideias marxistas e leninistas, na formação dessa organização revolucionária e na incorporação do elemento indígena na luta pelo socialismo na perspectiva do comunismo.

Na América Latina, a Revolução Mexicana de 1917 se despertava, abrindo possibilidades para reformas, rupturas e reordenamentos políticos e sociais nos estados latino-americanos. O debate intelectual gerado em decorrência da iminência dessas mudanças políticas e sociais se avolumava. A influência do movimento operário sindical europeu, do movimento popular e anti-imperialista mexicano e do movimento estudantil se manifestava com intensidade, questionando políticos e intelectuais sobre temas pertinentes às realidades sociais e históricas latino-americanas que demandavam transformações políticas, culturais, sociais e econômicas.

Neste cenário, destacamos as contribuições do peruano José Carlos Mariátegui. Ele foi um dos principais expoentes da cultura política comunista da América Latina, na primeira metade do século XX. Influenciado pelo marxismo, buscou, entre outras coisas, destacar a necessidade histórica da organização política da classe trabalhadora.

Mariátegui (2008) considera que a luta de classes se intensificou no Peru "com o nascimento de uma corrente socialista e o surgimento de uma consciência de classe no proletariado urbano" (MARIÁTEGUI, 2008, p. 90). Neste período, “[...] se afirma o padrão de desenvolvimento que vai articular, sob a hegemonia do imperialismo estadunidense, um capitalismo marcadamente monopolista com um conjunto econômico de características fortemente pré-capitalistas" (MARIÁTEGUI, 2008, p. 19). Dessa forma, configura-se o país de Mariátegui: "um país, em transição - a partir das estruturas econômico-sociais da república oligárquica, articulase a modernização controlada pelo imperialismo estadunidense" (ESCORSIM, 2006, p. 20). Ao apresentar uma crítica marxista em relação aos principais problemas peruanos, Mariátegui destaca a necessidade de tratar do problema indígena conectado à questão agrária, um aspecto fundamental da formação social e histórica peruana. 
Novidade no cenário peruano, o movimento estudantil traduz o "protagonismo político de um estrato social, cujas expectativas e demandas não cabiam no esquema civilista: o das camadas médias, proeminentes em especial em Lima e Callao" (ESCORSIM, 2006, p. 24). O principal traço característico do movimento estudantil "foi o de vincular as suas demandas específicas (Reforma Universitária) a exigências políticas e sociais que diziam respeito aos trabalhadores e grupos subalternos urbanos" (ESCORSIM, 2006, p. 25).

A criação da Universidade Popular González Prada (UPGP) é a principal indicadora da aliança estudantil-operária. Organizada pela "Federação dos Estudantes do Peru, em cuja frente estava Haya de la Torre, a UPGP dispunha de instrumentos editoriais como a revista Claridad e torna-se um viveiro de experiências pedagógicas e políticas" (ESCORSIM, 2006, p. 25), no Peru dos anos 1920.

Após constatar "a solidariedade do movimento estudantil com o movimento histórico geral desses povos", Escorsim (2006) trata de examinar as características próprias do movimento. Nesse exame, destaca-se a luta a favor da reforma universitária e:

[...] a fundação das Universidades Populares 'Gonzáles Prada', a adesão da juventude universitária ao princípio da socialização da cultura, as ascensões de um novo ideário educacional entre os professores interrompem definitivamente o diálogo erudito e acadêmico entre o espírito democrático liberal burguês e o espírito latifundiário e aristocrático. (ESCORSIM, 2006, p. 160).

Todavia, caberia ao movimento operário ser o componente mais fundamental no desfecho da crise da república oligárquica, pois "foi a sua ação, em 1919, que conduziu à derrocada de Pardo, e foi sua unidade com o movimento estudantil que fará com que, nos anos de 1920, os movimentos sociais tenham forte incidência na sociedade peruana" (ESCORSIM, 2006, p. 26).

Além das contribuições teóricas de Mariátegui (2008), com destaque para a defesa da incorporação dos povos indígenas na luta revolucionária, o exemplo de liderança política e de ação revolucionária por ele desenvolvida é fundamental, uma vez que: 
Além da atividade política-jornalística, José Carlos Mariátegui inclinou-se para a participação direta na vida política peruana. Criando em 1928, o Partido Socialista do Peru (PSP), transformado depois em Partido Comunista Peruano (PCP). Sendo-lhe atribuída a Secretária Geral (presidência) do novo partido e em 1929 a Confederação Geral dos Trabalhadores do Peru (CGTP). No auge de suas atividades, temendo represálias, transfere-se para Buenos Aires com sua família. José Carlos Mariátegui morre em abril de 1930, sendo homenageado no Peru e em círculos socialistas e comunistas de outros países. (ESCORSIM, 2006, p. 30 - 41).

Ao contribuir na formação da UPGP, na construção da Federação dos Estudantes e na da CGTP, Mariátegui trilha um caminho da organização e luta revolucionária através desses instrumentos políticos organizativos, vinculados à luta e à fundação do PSP que se transformou em PCP. Na atualidade três organizações comunistas peruanas reivindicam o legado deste revolucionário: o Partido Comunista do Peru (PC del P), o Partido Comunista Peruano (PCP) e o agrupamento comunista maoísta Sendero Luminoso.

\section{CONCLUSÃO}

O partido político é fundamental para o processo revolucionário, na medida em que a consciência socialista do proletariado não brotaria somente pela autoconsciência espontânea do trabalhador. É necessário que venha de fora para dentro. Cabe ao partido a execução dessa operação política, por meio de suas lutas cotidianas contra a ordem sócio-metabólica do capital.

Fica clara a subordinação do partido político (partido comunista) ao referencial teórico-prático do marxismo e do leninismo. A consciência superior é atribuída diretamente aos membros do partido. O objetivo central do operador político é a modificação completa da consciência, trabalhando na perspectiva da educação das massas e tendo como guia para ação a teoria revolucionária, ou seja, o marxismo. 
György Lukács (2012) destaca o papel do partido dirigente do proletariado, ao considerar que "Lênin foi o primeiro e, por muito tempo, o único líder teórico importante a considerar esse problema em seu aspecto teórico central e, por isso, decisivo na prática: o aspecto da organização" (LUKÁCS, 2012, p. 46).

O movimento comunista internacional atribui um papel de destaque em relação às questões da organização, da agitação e da propaganda. A formação humana dos quadros e militantes de um partido político é atribuída, desde as atividades práticas triviais até as tarefas de direção partidária, aulas preparatórias para atividade, autoeducação dos militantes e quadros dirigentes dessas organizações, por meio da práxis revolucionária.

$\mathrm{Na}$ perspectiva dos comunistas, cabe ao partido político de novo tipo, o partido comunista, a liderança e a direção política da classe trabalhadora em sua luta pelo poder, ou seja, o partido deve ser "uma vanguarda centralizada e empenhada em fundir teoria e a consciência socialista com o movimento operário espontâneo" (BOTTOMORE, 1988, p. 283).

Marcos Del Roio (2009) apresenta uma importante articulação entre Estado, política e partido, apontando que, em um primeiro momento, a indignação em relação à exploração e à consciência de classe do proletariado seria fundamental. Compreendendo que é o proletariado "o sujeito da transformação social e da emancipação humana", o caminho seria o do "encontro entre a filosofia da práxis e a auto-atividade operária" (DEL ROIO, 2009, p. 171). Neste sentido:

O passo seguinte foi o de se dar conta da necessidade do proletariado se constituir em classe e partido, dando forma a um movimento político voltado contra o capital e o Estado político. A política revolucionária seria então um meio necessário e transitório para confrontar a dominação econômica/ política da burguesia. A política revolucionária deve, pois, reverter a forma e o conteúdo da reprodução social que garante a exploração do trabalho e o poder político do capital. Parte essencial dessa ação é o empenho de se vincular trabalho e cultura. Vincular os indivíduos em uma nova comunidade na qual a 
sensibilidade do trabalho transcenda o estranhamento e se aproprie das fontes da vida e do conhecimento. O objetivo da emancipação humana nunca deixou, sequer por um momento, de estar no horizonte da reflexão e da ação de Marx. (DEL ROIO, 2009, p.171).

Cabe observarmos que o debate sobre o Estado na atualidade é fundamental para pensarmos na possibilidade objetiva da transição socialista. Ao longo da trajetória do movimento comunista, esta questão foi posta em segundo plano, dada a influência das concepções nacionalistas e democráticas nos partidos comunistas e nas organizações revolucionárias. A crítica marxista se esforça para retomar o debate acerca do Estado na sociedade capitalista. Muitos erros e equívocos do passado e da atualidade devemse ao abandono de elementos cruciais da tradição revolucionária marxista, como a compreensão da necessidade de superação do Estado, da concepção de política revolucionária e do papel de organização e luta dos partidos revolucionários.

Em seu texto A atualidade da ofensiva socialista, Mészáros (2010) destaca que, dado o fracasso dos partidos políticos ligados à II e III Internacional, não existe esperança para uma efetiva rearticulação do radicalismo socialista sem superar as contradições que necessariamente nascem da fracassada divisão entre o "braço político" e o "braço sindical" do trabalho. Apontando para a necessidade de rearticular a "força combativa material do trabalho produtivo" com os objetivos políticos de conquistar uma "mudança estrutural" (MÉSZÁROS, 2010, p. 69). Embora o autor faça essa afirmação, cabe notarmos que, dentro das organizações partidárias herdadas da II e III Internacionais, surgem agrupamentos revolucionários vinculados à perspectiva marxista da revolução social. Embora ainda numa fase embrionária, estas correntes e organizações tendem a crescer devido ao acirramento da luta de classes em nível internacional.

Mészáros (2010) salienta que a "negação prática materialmente efetiva das estruturas reprodutivas dominantes, através da ação e organização extraparlamentar, não implica a carência de leis ou mesmo a rejeição apriorística do próprio parlamento" (MÉSZÁROS, 2010, p. 98). No entanto, apresenta um desafio organizacional 
que deve ser superado pelo "trabalho enquanto antagonista do capital". Dada a predominância do "poder político do capital" no parlamento, fazem-se necessárias algumas formas de ação extraparlamentar capazes de exercer pressão sobre o legislativo e o executivo. As estratégias políticas limitadas aos marcos da democracia representativa liberal burguesa fracassaram na tentativa de promover transformações através da via institucional. Por outro lado, a via insurrecional através da luta armada das guerrilhas também apresentam limites intransponíveis.

Destacamos a necessidade da retomada de um dos traços determinantes mais importantes da tradição marxista: o internacionalismo proletário. Nesta perspectiva:

[...] a revolução social bem-sucedida não pode ser local ou nacional - apenas revoluções políticas podem se confinar a uma situação limitada, de acordo com sua própria parcialidade -, e sim global/universal, o que implica a transcendência do Estado em escala global. (MÉSZÁROS, 2011, p. 122).

Os três intelectuais revolucionários - Lênin, Gramsci e Mariátegui -, cada qual em seu contexto histórico, convergiram na perspectiva da construção de partidos revolucionários indispensáveis para a revolução socialista. As ideias fomentadas, desde a década de vinte do século passado, reforçam a necessidade histórica da organização política para dar sequência e sustentabilidade prática para a luta revolucionária. As contribuições destes intelectuais revolucionários apontam para a necessidade histórica do partido comunista para a luta revolucionária.

Na tradição revolucionária da cultura política socialista e comunista, a questão do partido é trivial. O operador político (partido), além de organizar os trabalhadores para o enfrentamento contra o capital, busca desenvolver a consciência socialista. Em outras palavras, cabe ao partido organizar, através das mediações necessárias, a classe trabalhadora e desenvolver a consciência de classe indispensável para o avanço dessa classe, na luta pelo socialismo na perspectiva do comunismo.

$\mathrm{Na}$ atualidade, existem diversos partidos políticos que se referenciam nas obras destes três revolucionários do século 
XX, em especial das contribuições de Lênin. No Brasil, existem várias organizações comunistas, tais como: o Partido Comunista Brasileiro (PCB), o Partido Comunista do Brasil (PCdoB), o Partido Comunista Revolucionário (PCR), o Polo Comunista Luís Carlos Prestes (PCLCP), o Partido Comunista Marxista-Leninista (PCML) e a Refundação Comunista $(\mathrm{RC})$. Estas organizações reivindicam o referencial teórico marxista e leninista, agregando contribuições de outros revolucionários. Os dois principais, PCB e PCdoB, se articulam em nível internacional com outros partidos comunistas através dos Encontros Internacionais de Partidos Comunistas e Operários (EIPCO) e se diferenciam em função das estratégias e táticas adotadas. O PCB adota uma estratégia socialista, pautando sua atuação principal junto aos movimentos sociais e populares da classe trabalhadora. O PCdoB busca aplicar uma estratégia nacional-democrática, dando prioridade à luta política nos marcos da institucionalidade.

Diversas correntes políticas ligadas a partidos socialistas e sociais-democratas também têm referência nestes três teóricos apresentados. Nas universidades e nos movimentos sociais e populares, pesquisas são desenvolvidas e cursos são ministrados relacionados às contribuições teóricas e políticas destes autores. Isso demonstra a forte influência exercida por estes teóricos na atualidade e reforça a necessidade da retomada, numa perspectiva crítica, da análise destas contribuições.

Desde 1917, a possibilidade objetiva da revolução alimenta sonhos de milhares de pessoas em todos os continentes do mundo. As contribuições desses intelectuais revolucionários alimentam esses sonhos que podem se tornar realidade. Retomar o debate acerca da necessidade do partido para o processo revolucionário é fundamental para pensarmos estrategicamente na luta revolucionária. Esta retomada deve partir da releitura destas contribuições e do fortalecimento das organizações, assim como se torna cada vez mais necessária a abordagem e a incorporação por parte dos partidos comunistas de lutas sociais importantes na atualidade, como, por exemplo, a questão ambiental. Outros outubros virão! 


\section{REFERÊNCIAS}

BOTTOMORE, T. Dicionário do pensamento marxista. São Paulo: Jorge Zahar, 1988.

CLAUDÍN, F. A crise do movimento comunista: o apogeu do stalinismo. v. 2. São Paulo: Global, 1986.

COUTINHO, C. N. (org.). O leitor de Gramsci. Rio de Janeiro: Civilização Brasileira, 2011.

DEL ROIO, M. Gramsci e o trabalho como fundamento da hegemonia. In: MENESES NETO, A. J. et. al. (orgs.). Trabalho, política e formação humana: interlocuções com Marx e Gramsci. São Paulo: Xamã. 2009. p. $157-172$.

ESCORSIM, L. Mariátegui vida e obra. São Paulo: Expressão Popular, 2006.

GRAMSCI, A. Concepção dialética da História. Rio de Janeiro: Civilização Brasileira, 1966.

HOBSBAWN, E. Como mudar o mundo: Marx e o Marxismo (1840-2011). São Paulo: Companhia das Letras, 2011.

LÊNIN. V. I. O que fazer?. São João Del Rei: Estudos Vermelhos, 2009.

O Estado e a revolução. Campinas: UNICAMP, 2011.

Sobre a educação. V. II. Lisboa: Seara Nova, 1977.

LUKÁCS, G. Lenin, um estudo sobre a unidade de seu pensamento. São Paulo: Boitempo Editorial, 2012.

MARIÁTEGUI, J. C. Sete ensaios de interpretação da realidade peruana. São Paulo: Expressão Popular, 2008.

MARX, K.; ENGELS, F. Manifesto do partido comunista. São Paulo: Hedra, 2011.

MÉSZÁROS, I. A atualidade da ofensiva socialista: uma alternativa radical ao sistema parlamentar. São Paulo: Boitempo, 2010.

A montanha que devemos conquistar: reflexões acerca do Estado. São Paulo: Boitempo, 2015.

Para além do capital: rumo a uma teoria de transição. São Paulo: Boitempo, 2011.

MOTTA, L. E. A favor de Althusser: revolução e ruptura na teoria marxista. Rio de Janeiro: Gramma, 2014.

NETTO, J. P. (org.). O leitor de Marx. Rio de Janeiro: Civilização Brasileira, 2012. 